\title{
Kontribusi Pengembangan Sumber Daya Manusia dalam Upaya Meningkatan Mutu Pendidikan Madrasah Aliyah Al-Amiriyyah Banyuwangi
}

\author{
Nur Hidayati ${ }^{1}$, Nayla Izza Kumala ${ }^{2}$ \\ e-mail : nurhidayati875@gmail.com ${ }^{1}$, naylazaza510@gmail.com ${ }^{2}$ \\ Prodi Manajemen Pendidikan Islam \\ Institut Agama Islam Darussalam Blokagung Banyuwangi
}

\begin{abstract}
The purpose in this study are: (1) To find out how is human resources of Madrasah Aliyah al-Amiriyyah Blokagung Tegalsari Banyuwangi 2019/2020 academic year; (2) To find out how the education quality of Madrasah Aliyah AlAmiriyyah Blokagung Tegalsari Banyuwangi 2019/2020 Academic Year; (3) To find out what are the factors that can improve the education quality of Madrasah Aliyah Al-Amiriyyah Blokagung Tegalsari Banyuwangi 2019/2020 Academic Year; (4) To realize the contribution of human resources development a which applied in improving the education quality of Madrasah Aliyah Al-Amiriyyah Blokagung Tegalsari Banyuwangi 2019/2020 Academic Year. This research method uses descriptive qualitative, data collection through interviews, observation and documentation. Data analysis uses interactive three models, while the data validity technique uses triangulation. Based on the clarification of inhibiting and supporting factors, the contribution of human resource development in improving the education quality of MA al-Amiriyyah Blokagung Tegalsari Banyuwangi can be explained as follows: (1) Teacher Training based on the respective fields of expertise held by the Religion Ministry. The human resources quality of educators and educational personnel is one of the factors in improving the quality of madrasas, by the qualified human resources quality, it is expected to produce cadres quality. (2) Direction from the Head of Education and Boarding School Caregiver, this briefing aims to provide motivation to educators and education staff.
\end{abstract}

Keywords: Development of Human Resources, Education Quality

\section{Abstrak}

Tujuan yang ditetapkan dalam penelitian ini adalah: (1) Untuk mengetahui bagaimana sumber daya manusia di Madrasah Aliyah al-Amiriyyah Blokagung Tegalsari Banyuwangi tahun pembelajaran 2019/2020; (2) Untuk mengetahui bagaimana mutu pendidikan di Madrasah Aliyah Al-Amiriyyah Blokagung Tegalsari Banyuwangi Tahun Pembelajaran2019/2020; (3) Untuk mengetahui apa saja faktor-faktor yang dapat meningkatkan mutu pendidikan di Madrasah Aliyah Al-Amiriyyah Blokagung Tegalsari Banyuwangi Tahun Pembelajaran2019/2020; (4) Untuk mengetahui kontribusi pengembangan sumber daya manusia yang diterapkan untuk meningkatkan mutu pendidikan di Madrasah Aliyah Al-Amiriyyah Blokagung Tegalsari Banyuwangi Tahun Pembelajaran 2019/2020. Metode penelitian ini menggunakan deskriptif kualitatif, pengumpulan datanya melalui wawancara, observasi dan dokumentasi. Analisis data menggunakan interaktif tiga model, sedangkan teknik keabsahan

Kontribusi Pengembangan Sumber Daya Manusia dalam Upaya Meningkatkan Mutu Pendidikan Madrasah Aliyah Al-Amiriyyah Blokagung Tegalsari Banyuwangi

Nur Hidayati, Nayla Izza Kumala 
data menggunakan triangulasi. Berdasarkan klarifikasi faktor penghambat dan pendukung maka diterapkan kontribusi pengembangan SDM dalam meningkatkan mutu pendidikan MA al-Amiriyyah Blokagung Tegalsari Banyuwangi sebagai berikut: (1) Pelatihan Guru Sesuai Bidang Keahlian Masing- Masing Yang Diadakan Oleh Kemenag.Kualitas SDM pendidik dan tenaga kependidikan merupakan salah satu faktor untuk meningkatkan mutu madrasah, karena dengan SDM yang berkualitas diharapkan dapat mencetak kader-kader yang berkualitas. (2) Pengarahan Dari Kabid Pendidikan Serta Pengasuh Pondok Pesantren, pengarahan ini bertujuan unuk memberikan motivasi kepada tenaga pendidik dan kependidikan.

Kata kunci: Pengembangan Sumber Daya Manusia, Mutu Pendidikan

\section{A. Pendahuluan}

\section{Latar Belakang Masalah}

Pengembangan sumber daya manusia merupakan suatu usaha berencana dengan menggunakan prosedur yang sistematis dan terorganisasi untuk mencapai penguasaan skill. Sesuai dengan pendapat Wexley dan Yulk (2013:282) bahwa "pengembangan sumber daya manusia adalah usaha-usaha berencana, yang diselenggarakan untuk mencapai pengetahuan, dan sikapsikap pegawai atau anggota organisasi”. Menurut Veithzal Rivai (2004:229) "tujuan utama pengembangan sumber daya manusia itu adalah melaksanakan kegiatan pendidikan bagi sumber daya manusia yang bekerja dan akan bekerja pada lembaga pendidikan sehingga mereka berkualitas dalam arti dapat mengembangkan kualitas mutu pendidikan mereka, mengembangkan diri mereka masing-masing, dan mengembangkan lingkungan masyarakat sekitarnya. Hal ini menunjukkan adanya keterkaitan antara pengembangan sumber daya manusia dengan mutu pendidikan dalam upaya meningkatkan kualitas mutu pendidikan. Karena semakin baik mutu pendidikan maka semakin berkualitas pula output pendidikan.

Berdasarkan wawancara peneliti kepada salah satu tenaga pendidik di Madrasah Aliyah Al-amiriyyah, bahwasannya di Madrasah Aliyah Alamiriyyah sudah ada sebuah kegiatan yang bertujuan untuk meningkatkan kualitas sumber daya manusia seperti peningkatan kualifikasi guru dan tenaga kependidikan serta implementasi sistem penjaminan mutu internal. Seperti adanya pelatihan- pelatihan sesuai bidang ahlinya masing-masing, dan juga adanya rapat rutinan beserta pengarahan dari pengasuh dan kabid 
pendidikan setiap satu bulan sekali. Penyataan tersebut oleh kepala sekolah MA al- Amiriyyah Blokagung Tegalsari Banyuwangi pada tanggal 24 april 2020 pukul 09.00 WIB.

"Ada beberapa kegiatan yang mengindikasikan pengembangan sumber daya manusia seperti pelatihan-pelatihan sesuai bidangnya, misalnya pelatihan administrasi untuk karyawan tata tsaha dan rapat rutinan beserta pengarahan dari pengasuh dan kabid pendidikan Pondok Pesantren Darussalam".

Program pengembangan sumber daya manusia di Madrasah Aliyah Al-amiriyyah karena merupakan bagian dari manajemen lembaga pendidikan. Sebagai bagian yang memberikan pengaruh besar pada mutu pendidikan dilembaga tersebut, hal ini pastinya tidak bisa di anggap sepele. Itulah sebabnya Madrasah Aliyah Al-amiriyyah harus terus mempersiapkan generasi yang tangguh dan siap bereksplorasi dengan segala kemampuan yang di miliki. Kemampuan yang dimiliki setiap sumber daya manusia harus terus di kembangkan hingga mampu memberikan kontribusi yang besar untuk pendidikan di Madrasah Aliyah Al-amiriyyah. Oleh karena itu peneliti menjadikan Madrasah Aliyah Al-amiriyyah sebagai objek penelitian dengan judul penelitian “ Kontribusi Pengembangan Sumber Daya Manusia dalam Meningkatkan Mutu Pendidikan Madrasah Aliyah al-Amiriyyah Tahun Pembelajaran 2019/2020.

\section{Tujuan Penelitian}

1. Mengetahui Pengembangan Sumber Daya Manusia di Madrasah Aliyah Al-Amiriyyah Blokagung Tegalsari Banyuwangi Tahun Pembelajaran $2019 / 2020 ?$

2. Mengetahui Mutu Pendidikan di Madrasah Aliyah Al-Amiriyyah Blokagung Tegalsari Banyuwangi Tahun Pembelajaran2019/2020?

3. Mengetahui Faktor-Faktor Yang Dapat Meningkatkan Mutu Pendidikan Di Madrasah Aliyah Al-Amiriyyah Blokagung Tegalsari Banyuwangi Tahun Pembelajaran2019/2020?

4. Mengetahui Kontribusi Pengembangan Sumber Daya Manusia Yang Diterapkan Untuk Meningkatkan Mutu Pendidikan Di Madrasah Aliyah

Al-Amiriyyah Blokagung Tegalsari Banyuwangi Tahun Pembelajaran Kontribusi Pengembangan Sumber Daya Manusia dalam Upaya Meningkatkan Mutu Pendidikan Madrasah Aliyah Al-Amiriyyah Blokagung Tegalsari Banyuwangi Nur Hidayati, Nayla Izza Kumala 
$2019 / 2020 ?$

\section{Manfaat Penelitian}

Setelah penelitian selesai dilaksanakan, maka diharapkan dapat memberikan manfaat antara lain sebagai berikut :

1. Manfaat Teoritis

Menambah wawasan terkait Pengembangan sumber daya manusia terhadap mutupendidikan.

2. Manfaat Praktis

a. Memberikan masukan untuk pengelola lembaga pendidikan dalams Pengembangan sumber daya manusia sebagai bagian dari peningkatan mutupendidikan.

b. Sebagai acuan untuk peneliti selanjutnya dengan tema yang sama menggunakan kajian yangmendalam.

\section{B. Tinjauan Pustaka}

\section{Kajian Teori Tentang Pengembangan Sumber Daya Manusia}

a. Pengertian Pengembangan Sumber Daya Manusia

Pengembangan adalah suatu usaha untuk meningkatkan kemampuan teknis, teoretis, konseptual dan moral karyawan sesuai dengan kebutuhan pekerjaan/jabatan melalui pendidikan dan latihan. Pendidikan sendiri berhubungan dengan peningkatan pengetahuan umum dan pemahaman atas lingkungan secara menyeluruh. Sedangkan latihan adalah suatu usaha peningkatan pengetahuan dan keahlian seorang karyawan untuk mengerjakan suatu pekerjaan tertentu. Menurut Jan Bella seperti yang dikutip Hasibuan (1997: 34) menyatakan bahwa : "pendidikan dan latihan sama dengan pengembangan yaitu merupakan proses peningkatan keterampilan kerja baik teknis maupun manajerial." Pendidikan berorientasi pada teori, dilakukan dalam kelas, berlangsung lama dan biasanya menjawab why. Latihan berorientasi pada praktek dilakukan di lapangan berlangsung singkat dan biasanya menjawab how.

Kontribusi Pengembangan Sumber Daya Manusia dalam Upaya Meningkatkan Mutu Pendidikan Madrasah Aliyah Al-Amiriyyah Blokagung Tegalsari Banyuwangi

Nur Hidayati, Nayla Izza Kumala 
Menurut Veithzal Rivai (2004: 229) “Tujuan utama pengembangan sumber daya manusia itu adalah melaksanakan kegiatan pendidikan bagi sumber daya manusia yang bekerja dan akan bekerja pada lembaga pendidikan sehingga mereka berkualitas dalam arti dapat mengembangkan lembaga pendidikan mereka, mengembangkan diri mereka masing-masing, dan mengembangkan lingkungan masyarakat sekitarnya".

Menurut Saydam (2006: 21) “pengembangan sumber daya manusia merupakan kegiatan yang harus dilaksanakan oleh lembaga pendidikan agar pengetahuan (knowladge), kemampuan (abality), dan keterampilan mereka sesuai dengan tuntutan pekerjaan yang mereka lakukan.” Sedangkan menurut Mangkunegara (2007:44) "pengembangan merupakan suatu peroses jangka panjang yang mempergunakan prosedur sistematis dan terorganisasi dimana pegawai manajerial mempelajari konsep dan teori guna mencapai tujuan yang umum.Menurut Robert dan Jackson (2002: 45) "Pengembangan Sumber Daya Manusia adalah usaha-usaha untuk meningkatkan kemampuan karyawan untuk menghadapi penugasan yaitu melalui: Pendidikan, Pelatihan".

Berdasarkan pendapat beberapa pakar di atas, dapat disimpulkan bahwa pengembangan sumber daya manusia dalah usaha-usaha yang dilakukan untuk meningkatkan pengetahuan dan keterampilan sumber daya manusia yang ada dilembaga pendidikan.

b. Indikator Pengembangan Sumber Daya Manusia

Menurut anwar prabu (2003: 56) Usaha-usaha untuk meningkatkan sumber daya manusia menghadapiberbagai penugasan yaitu:
1. Pendidikan
2. Pelatihan

\section{Kajian Teori Tentang Mutu Pendidikan}

a Pengetian Mutu Pendidikan

Kontribusi Pengembangan Sumber Daya Manusia dalam Upaya Meningkatkan Mutu Pendidikan Madrasah Aliyah Al-Amiriyyah Blokagung Tegalsari Banyuwangi

Nur Hidayati, Nayla Izza Kumala 
Dalam kamus besar bahasa Indonesia, mutu ialah ukuran baik buruk suatu benda. Sedangkan secara terminologi, istilah mutu memiliki pengertian yang cukup beragam, mangandung banyak tafsir dan bertentangan. Mutu menurut Fathurrohman (2012: 45) adalah "sebuah proses instruktur untuk memperbaiki keluaran yang dihasilkan". Sedangkan menurut Sujanto (2007: 116) "mutu pendidikan itu sendiri adalah bagaimana input peserta didik, proses penyelenggaraan pendidikan, hingga bagaimana hasil yang dikeluarkan".Kesimpulan dari definisi di atas ialah mutu pendidikan merupakan suatu ukuran yang dicapai dengan input, proses, dan output secara bertahap dan bagaimana tenaga kependidikannya bisa dilakukan semaksimal mungkin untuk mendapatkan kualitas atau mutu pendidikan yang lebihbaik.

b. Indicator Mutu Pendidikan

Menurut Sujanto (2007: 116) "peningkatan mutu pendidikan itu sendiri adalah bagaimana input peserta didik, proses penyelenggaraan pendidikan, hingga bagaimana hasil yang dikeluarkan".

1. Input Peserta Didik
a. Pemasaran internal
b. Profesionalisme

2. Proses Penyelenggaraan Pendidikan
a. Meningkatkan Mutu pembelajaran
b. Optimalisasi Peran Kepemimpinan

3. Output Pendidikan

Output pendidikan dilihat dari kualitas peserta didik ketika sudah lulus dari lembaga pendidikan tersebut.

\section{Metode Penelitian}

1. Jenis Penelitian

Penelitian ini menggunakan jenis penelitian deskriptif kualitatif yakni penelitian yang bersifat mendeskripsikan hasil penelitian sebagai Kontribusi Pengembangan Sumber Daya Manusia dalam Upaya Meningkatkan Mutu Pendidikan Madrasah Aliyah Al-Amiriyyah Blokagung Tegalsari Banyuwangi Nur Hidayati, Nayla Izza Kumala 
jawaban dari rumusan masalah penelitian dalam bentuk pemaparan apa yang dilihat, didengar, dirasakan, dan ditanyakan pada objek terkait untuk mendapatkan data secara fakta. Hal ini sesuai dengan yang diungkapkan oleh Sugiyono (2015 : 29): “menyatakan bahwa pada tahap deskripsi peneliti mendeskripsikan apa yang dilihat, didengar, dirasakan, dan ditanyakan untuk mendapatkan informasi dan data yang kemudian disusun secara jelas untuk mendapatkan hasil yang sesuai".

\section{Teknik Penentuan Informan}

Sesuai yang diungkapkan Sugiyono (2015: 300): “Teknik pemilihan informan snowball teknik pengambilan sumber data yang pada awalnya jumlahnya sedikit tersebut belum mampu memberikan data yang lengkap, maka mencari orang lain lagi yang dapat digunakan sebagai sumber data".

3. Teknik Keabsahan Data

Dalam penelitian ini pemeriksaan keabsahan data menggunakan modeltriangulasi yakni peneliti mengumpulkan data sekaligus memeriksa kebenarannya. Seperti yang diungkapkan oleh Sugiyono (2015: 330) menyatakan bahwa triangulasi dapat diartikan sebagai teknik pengumpulan data dan sumber data yangtelah ada sekaligus memeriksa kredibilitas data yang diperoleh melalui observasi, wawancara dan dokumentasi. Menurut Saebani dalam Imron (2016 : 67).

4. Teknik Analisis Data

Dalam penelitian ini untuk mengetahui kontribusi pengembagan sumber daya manusia dalam meningkatkan mutu pendidikan di MA al-Amiriyyah blokagung tegalsari banyuwangi dengan menggunakan analisis interaktif data tiga model sebagai berikut:
a. Reduksi Data
b. Penyajian Data
c. Menarik kesimpulan dan verivikasi

\section{Hasil Penelitian}

Berdasarkan paparan dan analisis data di atas maka diperoleh temuan data sebagai berikut:

Kontribusi Pengembangan Sumber Daya Manusia dalam Upaya Meningkatkan Mutu Pendidikan Madrasah Aliyah Al-Amiriyyah Blokagung Tegalsari Banyuwangi

Nur Hidayati, Nayla Izza Kumala 
1. Pengembangan Sumber Daya Manusia di Madrasah Aliyah al-Amiriyyah Blokagung Tegalsari Banyuwangi

Berdasarkan hasil wawancara mendalam peneliti dengan Kepala Sekolah, berikut ini hasil wawancaranya:

"Sumber daya manusia di MA al-Amiriyyah bisa dilihat dari 2 aspek, yakni kuantitas dan kualitas. Kuantitas sumber daya manusia di lembaga pendidikan ini menurut saya sudah cukup,baik guru dan staf karyawan lainnya. Untuk kualitas sumber daya manusia itu bisa dilihat dari keahliannya, dan guru- guru disini sudah mengajar sesuai mata pelajaran ahlinya. Dan juga untuk staf-staf lainnya juga sudah menempati ahlinya masing-masing, kemudian ada pengarahan dari pengasuh serta kabid pendidikan guna untuk menyelaraskan pemikiran.'(15 Juli 2020)

Pernyataan senada juga diungkapkan oleh WKS kurikulum, berikut ini hasil wawancaranya:

"Pengembangan Sumber daya manusia disini sudah baik, dilihat dari kinerjanya yang baik dan adanya pemberian pemenuhan kebutuhan yang berpengaruh terhadap etos kerja para tenaga kependidikan dan juga adanya pelatihan- pelatihan guna untuk meningkatkan etos kerja ." (15 Juli 2020)

Dari hasil wawancara dan dokumentasi yang peneliti lakukan dapat ditemukan bahwa pengembangan sumber daya manusia di MA alAmiriyyah secara kuantitas maupun kualitas sudah baik, dibuktikan dengan adanya tes seleksi guru secara tes tulis dan mikrotichingagar sesuai dengan kemampuan dan keahliannya masing- masing, adanya pemberian pemenuhan kebutuhan, adanya pemberian motivasi dari kepala sekolah, guna untuk memberikan semangat kerja.

2. Mutu Pendidikan di Madrasah Aliyah al-Amiriyyah Blokagung Tegalsari Banyuwangi

a. Selektif dalam rekruitmen peserta didik baru

Rekrutmen peserta didik baru dengan adanya verifikasiadmistrasi, tes akademik dengan sistem CBT, tes non akademik meliputi tes baca,tulis dan menghafal al-Quran serta tes interview kepribadian Sebagai upaya meningkatkan kualitas output peserta didik. MA al-Amiriyyah Blokagung Tegalsari Banyuwangi selektif dalam proses input peserta didik sebagaimana yang diungkapkan kepala MA al-Amiriyyah Blokagung Tegalsari

Banyuwangi berikut:

Kontribusi Pengembangan Sumber Daya Manusia dalam Upaya Meningkatkan Mutu Pendidikan Madrasah Aliyah Al-Amiriyyah Blokagung Tegalsari Banyuwangi

Nur Hidayati, Nayla Izza Kumala 
"Untuk mencapai visi dan misi madrasah, strategi yang digunakan adalah penjaringan siswa berprestasi pada saat proses rekrutmenpeserta didik baru melalui beberapa tes yang sudah disediakanmadrasah baik berupa tes akademik maupun non akademik". (15 Juli 2020)

Ungkapan tersebut sesuai dengan yang disampaikan WKS.

Kurikulumberikut:

"Untuk penerimaan peserta didik baru madrasah melakukan seleksi secara selektif baik di bidang akademik, non akademik, maupun administrasi”. (15 Juli 2020)

Informasi tersebut sesuai dengan pengamatan yang dilakukan penelitimengenai tahapan seleksi peserta didik baru di MA alAmiriyyah Blokagung Tegalsari Banyuwangi dandokumentasi yang ditemukan peneliti berupa beberapa tahapan tes bagipeserta didik baru.

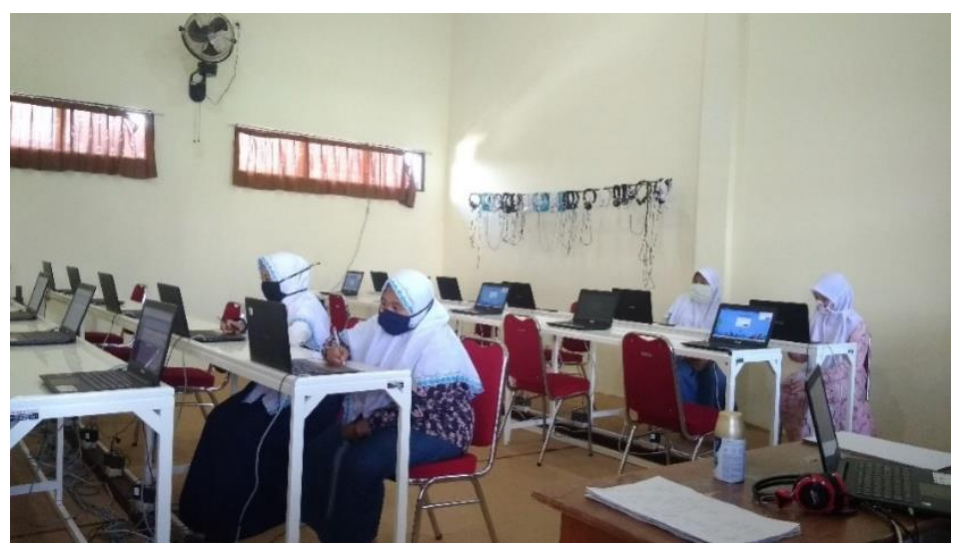

Gambar 4.1: Tes CBT peserta didik baru

Sumber : Dokumentasi MA al-Amiriyyah blokagung tegalsari

Banyuwangi

Berdasarkan gambar 4.1 tersebut terlihal calon peserta didik baru MA al-Amiriyyah Blokagung Tegalsari Banyuwangisedang melakukan tes ilmu pengetahuan atau tes tulis dengan menggunakan Computerbassic test (CBT), dengan adanya tes CBT akan memudahkan dalam auditnilai sehingga dengan cepat dapat mendapatkan nilai yang akurat. sedang melakukan tes ilmu pengetahuan atau tes tulis, akantetapi untuk tahun ini tes tulis Pendidikan Madrasah Aliyah Al-Amiriyyah Blokagung Tegalsari Banyuwangi

Nur Hidayati, Nayla Izza Kumala 
dilakukan dengan menggunakan Computerbassic test (CBT), dengan adanya tes CBT akan memudahkan dalam auditnilai sehingga dengan cepat dapat mendapatkan nilai yang akurat.

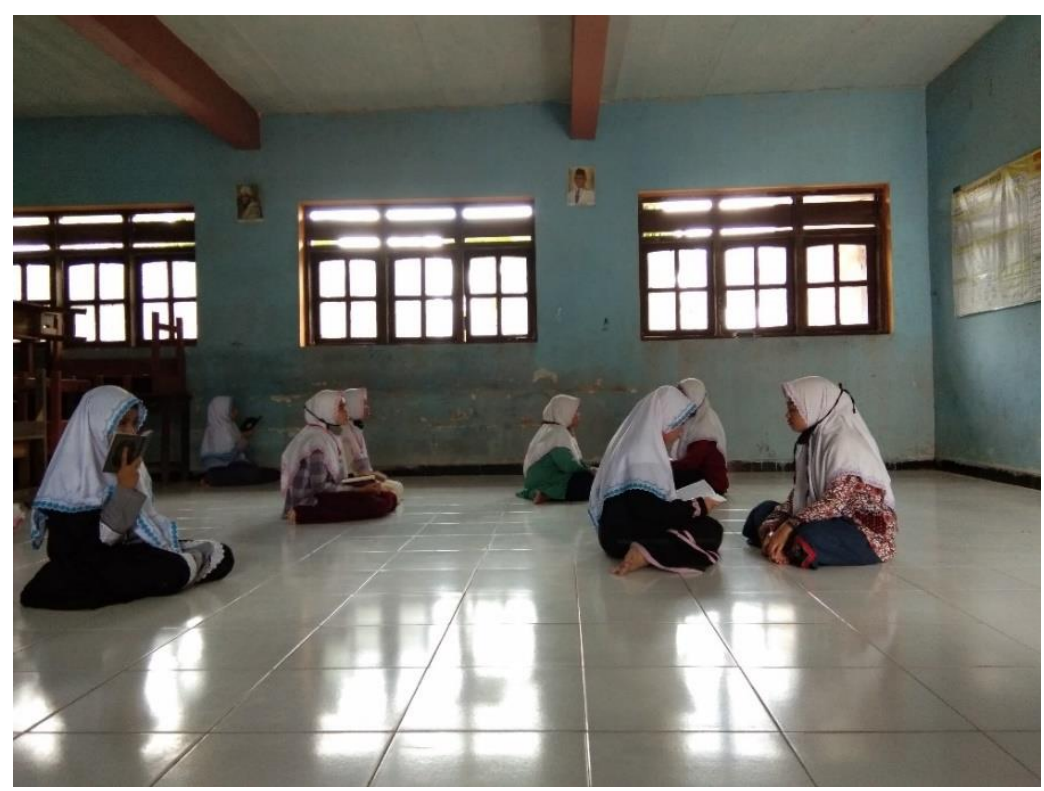

Gambar 4.2: Tes baca al-Quran

Sumber: Dokumentasi MA al-Amiriyyah

Dari gambar: 4.2 tersebut terlihat peserta didik baru antusias melakukan tes baca Al-Qur'an. Dalam tersebut akan dinilai kualitas bacaan Al-Qur'ancalon peserta didik baru, kelancaran membaca dan menulis Al-Qur'an.

Dengan demikian terlihat bahwa MA al-Amiriyyah Blokagung Tegalsari Banyuwangiselektif dalam prosesrekrutmen peserta didik.

b. Adanya inovasi sarana dan prasana di luar SNP

Sarana dan prasarana merupakan faktor penting dalam menunjangproses pembelajaran dan meningkatkan kualitas kemampuan baik pendidik dan peserta didik. Untuk itu MA alAmiriyyah Blokagung Tegalsari Banyuwangiberupaya untuk terus melengkapi sarana dan prasarana sesuai SNP dan sarana prasarana lain di luar SNP yang dapat menunjang proses belajar para peserta didik. Sebagaimana informasi yang disampaikan kepala MA al-Amiriyyah Kontribusi Pengembangan Sumber Daya Manusia dalam Upaya Meningkatkan Mutu Pendidikan Madrasah Aliyah Al-Amiriyyah Blokagung Tegalsari Banyuwangi

Nur Hidayati, Nayla Izza Kumala 
Blokagung Tegalsari Banyuwangikepada peneliti

berikut:

"Untuk menunjang semangat kepada siswi dalam belajar dan menghafal al- qur'an maka siswi unggulan tahfidz dan sains diberikan fasilitas asrama khusus. madrasah melengkapisarpras guna untuk menunjang proses pembelajaran". (15 Juli 2019)

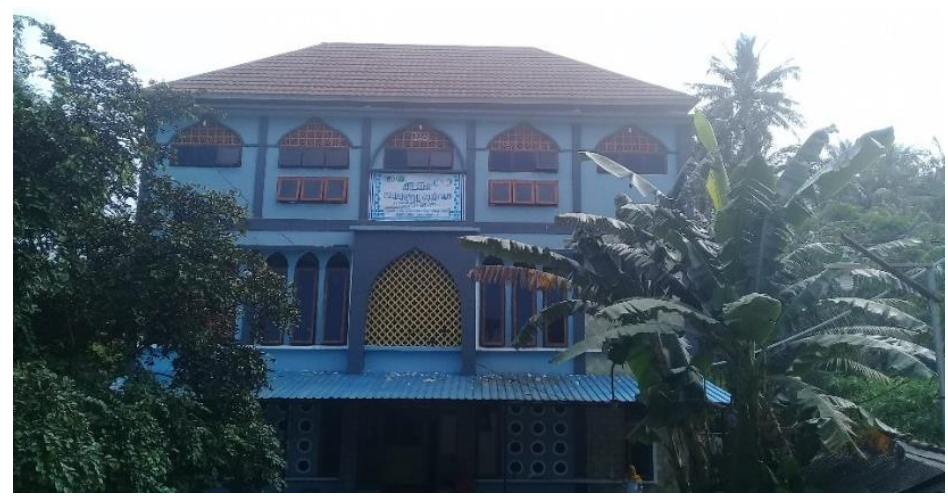

Gambar 4.3: asrama unggulan tahfidzul qur'an

Sumber: Dokumentasi MA al-Amiriyyah

Ungkapan yang serupa juga disampaikan oleh WKS.

Kurikulum berikut:

"Sarana dan prasarana yang ada di madrasah merupakan suatuperhatian penting kerena merupakan media untuk menunjang kemampuan siswa. Sehingga siswa tidak monoton dengan materi tetapi juga penerapannya". (15 Juli 2020)

Hasil wawancara tersebut sesuai dengan observasi yang dilakukan peneliti dilokasi penelitian dan data yang diperoleh peneliti berupa paparan sarana dan prasarana yang sesuai dengan SNP dan inovasi sarana prasarana dan termuat di lampiran 9.

c. Penghargaan (Reward) terhadap pendidik dan tenaga kependidikan sesuaiprestasi kinerja yang diperoleh dengan kenaikan jabatan

"Adapun reward yang diberikan pengelola madrasah atas kinerja pendidik maupun tenaga kependidikan yang ada di MA alAmiriyyah Blokagung Tegalsari Banyuwangitidak berupa uang tetapi berupa kenaikan pangkat lebih cepat sesuai dengan prestasi yang diperoleh seperti pak Ronul yang sekarang di bagian tata usaha meskipun pendidikan terakhirnya bukan perguruan tinggi seperti yang lainnya tetapi karena kerjanya bagus dan juga telaten maka pak Ronul direkrut menjadi tenaga pendidikan di bagian tata usaha".(15 Juli 
2020)

Informasi yang serupa juga disampaikan oleh salah satu tenaga pendidik MA al-Amiriyyah Blokagung Tegalsari Banyuwangi.

"Untuk memberi semangat dan motivasi dalam bekerja bagi dewan guru, bapak kepala memberikan promosi kenaikan jabatan lebih cepat sesuai dengan hasil kinerja dewan guru, sehingga dewan guru lebih semangat dan bersungguh-sungguh, tetapi yang terpenting adalah bekerja mencari ridho Allah". (15 Juli 2020)

Informasi lain juga disampaikan oleh WKS. Kurikulum terkait reward yang diberikan oleh pengelola MA al- Amiriyyah Blokagung Tegalsari Banyuwangi

"Untuk kenaikan jabatan tenaga pendidik dan kependidikan di MA al-Amiriyyah Blokagung Tegalsari Banyuwangi disesuaikan dengan kinerja yang dilakukan, misalkandengan kepala bidang pada tugasnya masing-masing”. (15 Juli 2020)

Dari hasil wawancara yang peneliti lakukan dengan beberapa tenaga pendidik dan kependidikan di lokasi penelitian dapat disimpulkan bahwa penghargaan (reward) yang diberikan pengelola MA al- Amiriyyah Blokagung Tegalsari Banyuwangi berupa kenaikan jabatan dan diperkuat dengan observasi yang dilakukan peneliti terkait informasi yang disampaikan oleh kepala madrasah.

d. Pendampingan calon output peserta didik dalam study kampus

Untukmengetahui informasi perguruan tinggi secara faktualUpaya yang dilakukan pengelola madrasah dalam mengawal pesertadidik ke jenjang pendidikan selanjutnya dengan melakukan study kampus kebeberapa perguruan tinggi negeri maupun ke perguruan tinggi swasta yangbonafit. Hal tersebut sesuai dengan yang disampaikan kepala madrasah berikut:

"Output MA al- Amiriyyah Blokagung Tegalsari Banyuwangi diharapkan dapat diterima di beberapa PTN se Indonesia maupun PTS yang bonafit. Untuk itu anak-anak disuguhkan atau diberi kesempatan untuk mencari informasi tentang perguruan tinggi secara nyata dengan melakukan study kampus". (15 Juli 2020)

Informasi yang serupa juga disampaikan oleh WKS.

Kurikulum dengan peneliti berikut:

Kontribusi Pengembangan Sumber Daya Manusia dalam Upaya Meningkatkan Mutu Pendidikan Madrasah Aliyah Al-Amiriyyah Blokagung Tegalsari Banyuwangi

Nur Hidayati, Nayla Izza Kumala 
"Untuk peserta didik yang akan lulus atau calon output, anakanak diberi kesempatan untuk mencari informasi tentang beberapa perguruan tinggi negeri sesuai dengan peminatan atau kompetensisiswa dengan melakukan study kampus". (15 Juli 2020)

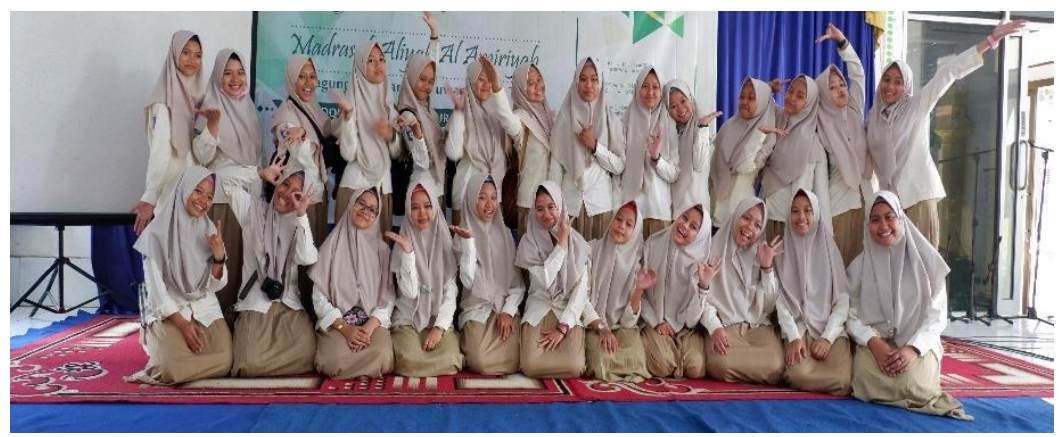

Gambar 4.4: Study kampus calon output MA al-Amiriyyah

Sumber: Dokumentasi MA al-Amiriyyah

Dari gambar 4.4 tersebut dapat diketahuai bahwa pengelola MA al-Amiriyyah Blokagung Tegalsari Banyuwangi aktif mengawal peserta didik calon output dalam melanjutkan jenjang pendidikan selanjutnya ke jenjang perguruan tinggi negeri se Indonesia maupun perguruan tinggi swasta yang bonafit.

3. Faktor-Faktor Yang Dapat Meningkatkan Mutu Pendidikan di Madrasah Aliyah al-Amiriyyah Blokagung Tegalsari Banyuwangi

Berdasarkan wawancara kepada kepala sekolah tentang faktorfaktor yang dapat meningkatkan mutu pendidikan di MA al-Amiriyyah Blokagung Tegalsari Banyuwangimeliputi faktor pendukung dan faktor penghambat yang ada di MA al-Amiriyyah Blokagung Tegalsari Banyuwangi.

a. Faktor pendukung meliputi kekuatan dan peluang yang ada di MA alAmiriyyah Blokagung Tegalsari Banyuwangi

Berdasarkan paparan data yang sudah dipaparkan dapat diketahuibeberapa faktor yang dapat mendukung MA al-Amiriyyah Blokagung Tegalsari Banyuwangi dalammeningkatkan mutu pendidikan yaitu: tenaga pendidik dan kependidikan $40 \%$ adalah 
alumni pondok pesantren sehingga tercipta nuansa religius di lingkungan madrasah, adanya inovasi sarana dan prasarana pendidikan di luarSNP, pelaksanaan kegiatan melibatkan stakeholder internal dan eksternaluntuk mengoptimalkan pelaksanaan program dalam pencapaian mutu yangditetapkan.

b. Faktor penghambat meliputi kelemahan dan tantangan di MA alAmiriyyah Blokagung Tegalsari Banyuwangi

Berdasarkan paparan data yang sudah dipaparkan dapat diketahui beberapa faktor yang dapat mendukung MA al-Amiriyyah Blokagung Tegalsari Banyuwangi dalam meningkatkan mutu pendidikan yaitu: latar belakang tenaga pendidik dankependidikan yang tidak semuanya merupakan lulusan pesantren sehinggakurangnya kesadaran diri dalam beberapa kegiatan yang bernuansa religius.

4. Kontribusi Pengembangan Sumber Daya Manusia Yang Diterapkan Untuk Meningkatkan Mutu Pendidikan Di Madrasah Aliyah al-Amiriyyah Blokagung Tegalsari Banyuwangi

Setelah diklarifikasikan faktor penghambat dan faktor pendukung, menyimpulkan bahwa kontribusi pengembangan SDM yang diterapkan untuk meningkatkan mutu pendidikan di MA al-Amiriyyah Blokagung Tegalsari Banyuwangi sebagai berikut:

a. Pelatihan Guru Sesuai Bidang Keahlian Masing-Masing Yang Diadakan Oleh Kemenag

Kualitas SDM pendidik dan tenaga kependidikan merupakan salah satufaktor untuk meningkatkan mutu madrasah, karena dengan SDM yangberkualitas diharapkan dapat mencetak kader-kader yang berkualitas pula.Untuk itu, pengelola MA alAmiriyyah Blokagung Tegalsari Banyuwangi dalam upaya peningkatan SDM tenaga pendidikdan kependidikan dengan mengikutsertakan dalam beberapa pelatihan sesuaidengan tugas dan bidangnya masing-masing yang diadakan oleh Kemenag.Hal tersebut sesuai dengan informasi yang disampaikan kepala MA al-Amiriyyah Pendidikan Madrasah Aliyah Al-Amiriyyah Blokagung Tegalsari Banyuwangi

Nur Hidayati, Nayla Izza Kumala 
Blokagung Tegalsari Banyuwangi berikut:

"Untuk meningkatkan kualitas SDM pendidik dan tenaga kependidikanmadrasah selalu mengikutsertakan dalam beberapa pelatihan sesuaidengan bidangnya masing-masing, sebelum pelatihan tersebut diadakan maka akan ada analisis jabatan terlebih dahulu, untuk mengetahui pelatihan yang sesuai pada bidang ahlinya, setelah itu ada tes psikologis, kemudian penyelidikan sikap/moral, kemudian barulah pelatihan dilakukan. seperti contoh guru BK yamengikuti pelatihan guru BK dan lain sebagainya sesuai denganbidangnya masing-masing yang diadakan oleh Kemenag". (15 Juli 2020)

Informasi yang serupa juga disampaikan oleh staf Tata

Usaha MA al-Amiriyyah Blokagung Tegalsari Banyuwangi berikut:

"Madrasah sering mengikutsertakan pelatihan ke tata usahaan, untuk melatih masalah- masalah keadministrasi yang dihadapi madrasah ". (15 Juli 2020)

Hasil wawanacara tersebut sesuai dengan observasi dan dokumentasi yangditemukan peneliti berupa salah satu pelatihan kurikulum madrasah dan pelatihan keadministrasian untuk bidang tata usaha. Hal tersebutmembuktikan bahwa pengelola MA al-Amiriyyah aktif berperan dalamupaya pengembangan kualitas SDM pendidik dan tenaga kependidikan di MA al-Amiriyyah Blokagung Tegalsari Banyuwangi.

b. Pengarahan Dari Kabid Pendidikan dan Pengasuh Pondok Pesantren Pengarahan ini bertujuan unuk memberikan motivasi kepada tenaga pendidik dan kependidikan.

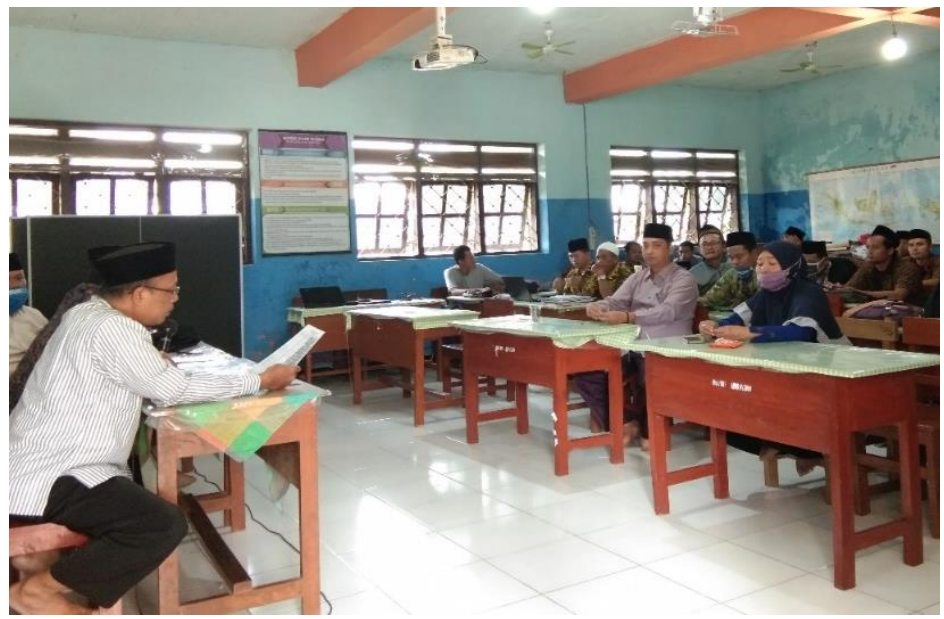

Gambar 4.5 rapat rutinan sekaligus pengarahan dari pengasuh

Sumber : Dokumentasi MA al-Amiriyyah

Kontribusi Pengembangan Sumber Daya Manusia dalam Upaya Meningkatkan Mutu Pendidikan Madrasah Aliyah Al-Amiriyyah Blokagung Tegalsari Banyuwangi

Nur Hidayati, Nayla Izza Kumala 


\section{E. Pembahasan}

\section{Pengembangan Sumber Daya Manuisa di MA al-Amiriyyah Blokagung Tegalsari Banyuwangi}

Dalam rangka upaya meningkatkan etos kerja guru dan kinerja guru, berdasarkan waancara kepada kepala sekolah MA al-Amiriyyah Blokagung Tegalsari Banyuwangi, makaseorang pemimpin dalam hal ini kepala Madrasah memberikan pemenuhan kebutuhan sebagai berikut:

a. Adanya tes tulis dan microtiching untuk calon tenaga pendidik dan kependidikan, agar bisa bekerja maksimal sesuai bidang keahliannya masing- masing.

b. Pengembangan sumber daya manusia dengan pemberian bisyaroh di setiap bulannya, bisyaroh tersebut bertujuan untuk menambahkan semangat kinerja tenaga kependidikan.

c. pemberian motivasi ketika diadakannya rapat rutinan tenaga pendidik dan kependidikan.

d. Pemberian penghargaan kepada tenaga kependidikan yang kinerjanya baik.

\section{Mutu Pendidikan MA al-Amiriyyah Blokagung Tegalsari Banyuwangi}

a. Selektif dalam rekruitmen peserta didik baru

Rekrutmen peserta didik baru dengan adanya verifikasiadmistrasi, tes akademik dengan sistem CBT, tes non akademik meliputi tes baca,tulis dan menghafal al-Quran serta tes interview kepribadian Sebagai upaya meningkatkan kualitas output peserta didik. MA al-Amiriyyah Blokagung Tegalsari Banyuwangi selektif dalam proses input peserta didik. .

b. Adanya inovasi sarana dan prasana di luar SNP

Sarana dan prasarana merupakan faktor penting dalam menunjangproses pembelajaran dan meningkatkan kualitas kemampuan baik pendidik dan peserta didik. Untuk itu MA al-Amiriyyah Blokagung Tegalsari Banyuwangiberupaya untuk terus melengkapi sarana dan prasarana sesuai SNP dan sarana prasarana lain di luar SNP yang dapat menunjang proses belajar para peserta didik. Sarana dan prasarana diluar 
SNP tersebut adalah adanya asrama khusus siswi program unggulan tahfidz dan Sains, guna untuk menunjang penambahan semangat dari siswi unggulan tersebut.

c. Penghargaan (Reward) terhadap pendidik dan tenaga kependidikan sesuai prestasi kinerja yang diperoleh dengan kenaikan jabatan

Sebagai apresiasi terhadap kinerja pendidik dan tenaga kependidikan di MA al-Amiriyyah Blokagung Tegalsari Banyuwangi, pengelola MA al-Amiriyyah Blokagung Tegalsari Banyuwangimemberikan penghargaan (reward) berupa kenaikan pangkat lebih cepat.

d. Pendampingan calon output peserta didik dalam study kampus

Untukmengetahui informasi perguruan tinggi secara faktualUpaya yang dilakukan pengelola madrasah dalam mengawal pesertadidik ke jenjang pendidikan selanjutnya dengan melakukan study kampus kebeberapa perguruan tinggi negeri maupun ke perguruan tinggi swasta yangbonafit.

Pengelola MA al-Amiriyyah Blokagung Tegalsari Banyuwangi aktif mengawal peserta didik calon output dalam melanjutkan jenjang pendidikan selanjutnya ke jenjang perguruan tinggi negeri se Indonesia maupun perguruan tinggi swasta yang bonafit.

\section{Faktor-Faktor Yang Dapat Meningkatkan Mutu Pendidikan di} Madrasah Aliyah al-Amiriyyah Blokagung Tegalsari Banyuwangi

Faktor-faktor yang dapat meningkatkan mutu pendidikan di MA alAmiriyyah Blokagung Tegalsari Banyuwangi meliputi faktor pendukung dan faktor penghambat yang ada di MA al-Amiriyyah Blokagung Tegalsari Banyuwangi:

a. Faktor pendukung meliputi kekuatan dan peluang yang ada di MA alAmiriyyah Blokagung Tegalsari Banyuwangi

Berdasarkan paparan data yang sudah dipaparkan dapat diketahuibeberapa faktor yang dapat mendukung MA al-Amiriyyah Blokagung Tegalsari Banyuwangi dalammeningkatkan mutu pendidikan yaitu: tenaga pendidik dan kependidikan40\% adalah alumni pondok Kontribusi Pengembangan Sumber Daya Manusia dalam Upaya Meningkatkan Mutu Pendidikan Madrasah Aliyah Al-Amiriyyah Blokagung Tegalsari Banyuwangi Nur Hidayati, Nayla Izza Kumala 
pesantren sehingga tercipta nuansa religius di lingkungan madrasah, adanya inovasi sarana dan prasarana pendidikan di luarSNP, pelaksanaan kegiatan melibatkan stakeholder internal dan eksternaluntuk mengoptimalkan pelaksanaan program dalam pencapaian mutu yangditetapkan.

b. Faktor penghambat meliputi kelemahan dan tantangan di MA alAmiriyyah Blokagung Tegalsari Banyuwangi

Berdasarkan paparan data yang sudah dipaparkan dapat diketahui beberapa faktor yang dapat mendukung MA al-Amiriyyah Blokagung Tegalsari Banyuwangi dalam meningkatkan mutu pendidikan yaitu: latar belakang tenaga pendidik dankependidikan yang tidak semuanya merupakan lulusan pesantren sehinggakurangnya kesadaran diri dalam beberapa kegiatan yang bernuansa religius.

\section{Kontribusi Pengembangan Sumber Daya Manusia Yang Diterapkan}

\section{Untuk Meningkatkan Mutu Pendidikan Di Madrasah Aliyah al-}

\section{Amiriyyah Blokagung Tegalsari Banyuwangi}

Berdasarkan wawancara kepada kepala sekolah dan staf tata usaha menyimpulkan bahwa kontribusi pengembangan SDM untuk meningkatkan mutu pendidikan di MA al-Amiriyyah Blokagung Tegalsari Banyuwangi sebagai berikut:

a. Pelatihan Guru Sesuai Bidang Keahlian Masing- Masing Yang Diadakan Oleh Kemenag

b. Pengarahan Dari Kabid Pendidikan Serta Pengasuh Pondok Pesantren

\section{F. Kesimpulan}

1. Kontribusi Pengembangan Sumber Daya Manuisa di MA al-Amiriyyah Blokagung Tegalsari Banyuwangi

(1)Adanya tes tulis dan microtiching untuk calon tenaga pendidik dan kependidikan, agar bisa bekerja maksimal sesuai bidang keahliannya masing- masing. (2) Pengembangan sumber daya manuisa dengan pemberian bisyaroh di setiap bulannya, bisyaroh tersebut bertujuan untuk Kontribusi Pengembangan Sumber Daya Manusia dalam Upaya Meningkatkan Mutu Pendidikan Madrasah Aliyah Al-Amiriyyah Blokagung Tegalsari Banyuwangi Nur Hidayati, Nayla Izza Kumala 
menambahkan semangat kinerja tenaga kependidikan.(3) Pemberian motivasi ketika diadakannya rapat rutinan anggota kependidikan.(4) Pemberian penghargaan kepada tenaga kependidikan yang kinerjanya baik.

2. Mutu pendidikan MA al-Amiriyyah Blokagung Tegalsari Banyuwangi

Peningkatan mutu pendidikan pada MA al-Amiriyyah Blokagung Tegalsari Banyuwangi meliputi. (1) Selektif dalam rekruitmen peserta didik baru dengan adanya verifikasi admistrasi, tes akademik dengan sistem CBT, tes non akademik meliputi tes baca,tulis dan menghafal alQuran serta tes interview kepribadian . (2)Adanya inovasi sarana dan prasana di luar SNP, Sarana dan prasarana diluar SNP tersebut adalah adanya asrama khusus siswi program unggulan tahfidz dan Sains, guna untuk menunjang penambahan semangat dari siswi unggulan tersebut. (3) Penghargaan (Reward) terhadap pendidik dan tenaga kependidikan sesuai prestasi kinerja yang diperoleh dengan kenaikan jabatan. (4) Pendampingan calon output peserta didik dalam study kampus untuk mengetahui informasi perguruan tinggi secara faktual.

3. Faktor-Faktor Yang Dapat Meningkatkan Mutu Pendidikan di Madrasah Aliyah al-Amiriyyah Blokagung Tegalsari Banyuwangi

Faktor-faktor yang dapat meningkatkan mutu pendidikan di MA al-Amiriyyah Blokagung Tegalsari Banyuwangi meliputi faktor pendukung dan faktor penghambat yang ada di MA al-Amiriyyah Blokagung Tegalsari Banyuwangi :

a. Faktor pendukung meliputi: (1) tenaga pendidik dan kependidikan $40 \%$ adalah alumni pondok pesantren sehingga tercipta nuansa religius di lingkungan madrasah. (2) adanya inovasi sarana dan prasarana pendidikan di luar SNP.

b. Faktor penghambat yaitu: latar belakang tenaga pendidik dan kependidikan yang tidak semuanya merupakan lulusan pesantren sehingga kurangnya kesadaran diri dalam beberapa kegiatan yang bernuansa religius.

4. Kontribusi Pengembangan Sumber Daya Manusia Yang Diterapkan Untuk Kontribusi Pengembangan Sumber Daya Manusia dalam Upaya Meningkatkan Mutu Pendidikan Madrasah Aliyah Al-Amiriyyah Blokagung Tegalsari Banyuwangi

Nur Hidayati, Nayla Izza Kumala 
Meningkatkan Mutu Pendidikan Di Madrasah Aliyah al-Amiriyyah Blokagung Tegalsari Banyuwangi

(1) Pelatihan Guru Sesuai Bidang Keahlian Masing- Masing Yang Diadakan Oleh Kemenag.Kualitas SDM pendidik dan tenaga kependidikan merupakan salah satu faktor untuk meningkatkan mutu madrasah, karena dengan SDM yang berkualitas diharapkan dapat mencetak kader-kader yang berkualitas. (2) Pengarahan Dari Kabid Pendidikan Serta Pengasuh Pondok Pesantren, pengarahan ini bertujuan unuk memberikan motivasi kepada tenaga pendidik dan kependidikan.

\section{G. Saran}

Berdasarkan hasil penelitian dan kesimpulan tersebut di atas, disampaikan

beberapa saran kepada pengelola madrasah dan peneliti selanjutnya sebagai berikut:

1. Diharapkan pengelola MA al-Amiriyyah Blokagung Tegalsari Banyuwangi mampu mengembangkan sumber daya manusia dengan lebih baik lagi untuk meningkatkan etos kerja.

2. Diharapkan tenaga pendidik maupun kependidikan MA al-Amiriyyah Blokagung Tegalsari Banyuwangi mampu lebih meningkatkan mutu pendidikan guna mencapai visi, misi, dan tujuan madrasah.

3. Diharapkan memanfaatkan faktor pendukung berupa kekuatan dan peluang untuk meningkatkan mutu pendidikan MA al-Amiriyyah Blokagung Tegalsari Banyuwangi semakin baik serta meminimalisir faktor penghambat berupa kelemahan dan tantangan dan dicarikan solusi alternatif agar tidak menghambat peningkatan mutu pendidikan pada MA al-Amiriyyah Blokagung Tegalsari Banyuwangi.

4. Diharapkan penerapan pengembangan sumber daya manusia di MA alAmiriyyah Blokagung Tegalsari Banyuwangi dapat meningkatkan kualitas mutu pendidikan di sekolahan tersebut.

\section{H. Daftar Pustaka}

Kontribusi Pengembangan Sumber Daya Manusia dalam Upaya Meningkatkan Mutu Pendidikan Madrasah Aliyah Al-Amiriyyah Blokagung Tegalsari Banyuwangi

Nur Hidayati, Nayla Izza Kumala 
Barthos, Basir. 2004. Manajemen Sumber Daya Manusia. Jakarta: Bumi Aksara

Fathurrohman, Muhammad, dan Sulistyorini. 2012. Implementasi Peningkatan Mutu Pendidikan Islam. Yogyakarta: Teras

Gilley dan Steven. 2002. Kualitas pendidikan. Bandung: Petaka

Gouzali Saydam. 1998. Ilmu Pendidikan Islam, Cet. 1. Jakarta: Kalam Mulia Hamalik. 2007. Manajemen Mutu Pendidikan. Jakarta: Bumi Aksara

Hasibuan . 1997. Manajemen sumber daya manusia. Jakarta: Bumi Aksara

Hidayat, Rahmat dan Candra Wijaya. 2017. Ayat-Ayat Al-Qur'an Tentang

Manajemen Pendidikan Islam. Medan: Lembaga Peduli Pengembangan Pendidikan Islam

Komarrudin. 2012. Paradigma Baru Manajemen Sumber Daya Manusia,

Cet. I. Yogyakarta: Amara Book

Notoatmodjo soekidjo. 2015. Pengembangan Sumber daya manusia. Jakarta: Rineka Cipta

Prabu, Anwar. 2003. Perencanaan Dan Pengembangan Sumber Daya Manusia. Bandung: Ikapi

Sallis Edward. 2012. TQM manajemen mutu pendidikan. Jogjakarta: Ircisod Sonny Sumarsono. 1979. Filsafat Administrasi, Cet. I. Jakarta: Gunung Agung

Sudarwan Danim. 2000. Perencanaan sumber daya manusia. Bandung:Bumi Aksara

Sugiono. 2015. Metode Penelitian Pendidikan. Bandung: Alfabeta

Sugiono. 2016. Metode Penelitian Kuantitatif, Kualitatif. Bandung: Alfabeta Sujanto. 2007. Pendidikan bermutu. Surabaya: Aditama 